\title{
SEVENTY YeARs OF DOGMATICS AND Christian ETHICS AT THE UNIVERSITY of Pretoria: A Dutch reformed Perspective
}

Author:

Conrad Wethmar ${ }^{1}$

\section{Affiliation:}

${ }^{1}$ Department Dogmatics and Christian Ethics,

University of Pretoria,

South Africa

\section{Correspondence to:}

Conrad Wethmar

e-mail:

wethmar@up.ac.za

Postal address:

The Ring 10, Lynnwood,

0081, Pretoria, South Africa

\section{Keywords:}

dogmatics; Christian ethics;

University of Pretoria;

Dutch Reformed Church;

Department of Dogmatics and Christian Ethics

\section{Dates:}

Received: 27 Nov. 2008

Accepted: 09 Sept. 2009

Published: 17 Dec. 2009

How to cite this article: Wethmar, C., 2009, 'Seventy years of dogmatics and Christian ethics at the University of Pretoria: A Dutch reformed perspective', Verbum et Ecclesia 30(3), Art. \#184, 9 pages. DOI: 10.4102/ ve.v30i3.184

\section{This article is available} at:

http://www.ve.org.za (c) 2009. The Authors. Licensee: OpenJournals Publishing. This work is licensed under the Creative Commons Attribution License.

\begin{abstract}
This article provides a brief analysis and evaluation of the work done by the Department of Dogmatics and Christian Ethics at the University of Pretoria during its history of 70 years. The respective periods of tenure of the successive members of staff were extensive enough to serve as a basis for distinguishing between various phases in the development of the Department. In each of the phases, a significant and distinctive contribution was made to the academic enterprise of the Faculty of Theology, as well as to the work of the Dutch Reformed Church which was represented by the relevant members of staff.
\end{abstract}

\section{INTRODUCTION}

Having to provide a brief survey of the history of an academic department that has been in operation for a considerable period of time is a demanding task, due to the length of time covered, as well as the wide range of issues that require attention. Such a range includes consideration of the various notions and definitions of a particular academic discipline, which developed during the different stages in the history of the discipline, as well as the different didactic methods, according to which such a discipline has been taught. The question could also be asked whether the body of knowledge in the relevant discipline increased over the course of time, or whether it merely consisted of repeating and reformulating the same unaltered insights. How the pursuit of a specific discipline is influenced by changing political and cultural circumstances should also be considered, as well as whether the language in which teaching and research is conducted has any influence on the results achieved. In the case of a theological discipline, the question could also be asked as to which of the various schools of thought that developed over the course of time was influential with regard to the way in which the subject was dealt with in the relevant department. The questions of a more practical nature that could be asked are: What was the influence of the administrative procedures according to which matters in the relevant department were managed in regards to the academic achievements of the department? What were the policies and criteria according to which members of staff were appointed?

Dealing with all the above issues in an adequate and satisfactory way in a brief survey is impossible. It has, therefore, been decided to describe the various phases in the development of the Department of Dogmatics and Christian Ethics by briefly discussing the life and work of the teaching staff who, throughout the years, have been involved in the work of the Department. The presupposition is that there exists a reciprocal interaction between biography and theology (Weinrich 1999:9). Such a discussion would, hopefully, enable us to deal with as many of the above-mentioned questions as possible.

In most cases, the tenure of the lecturers in the Department lasted for such a long time that the respective periods of their involvement could be regarded as being indicative of specific phases in the history of the Department. Due to the fact that a certain historical distance is necessary to obtain a clear picture and fair assessment of the contribution of a particular individual, it has also been decided to devote more space to past members of staff than to those who still hold office. Apart from the fact that the work of the former is complete, a further reason for taking such an approach is that, in the meantime, a considerable amount of literature and other material has become available regarding those earlier members of staff. The result is that more information is readily available on them than it is on the currently serving members.

The intention of the subtitle of the present article is to emphasise a deliberate restriction that has to be taken into account. From 1938 to 1999 the University of Pretoria had two separate faculties of Theology and, consequently, also two separate departments of Dogmatics and Christian Ethics. In 2000 the faculties and departments concerned amalgamated (Wethmar 2003a:63). The fact that a process, which in 1938 seemed impossible, became a reality in 2000, poses interesting questions of an historical and theological nature. Such questions belong intrinsically to the topic of this article, which means that a discussion of the contributions of the representatives of the Hervormde Kerk and the Presbyterian Church should have been included in this presentation. For practical reasons, however, such discussion will be dealt with at a later stage.

On the cornerstone alongside the entrance to the Theology building on the Pretoria University campus the well-known saying of Hippocrates ars longa vita brevis has been inscribed. The immense scope of the academic enterprise - and this applies also, and especially, where theology is concerned - by far exceeds the capacity of any involved in it. An academic department that holds by such a Hippocratean saying should fittingly compare its achievements with the expectations that have been harboured about it. This would especially be the case in a year in which the University of Pretoria celebrates its centenary and the Dutch Reformed section of the Faculty its 70th anniversary. With all this in mind, the current article intends to provide a brief description and assessment of the lives and work of the lecturers who, for the past 70 years, have taught Dogmatics and Christian Ethics at the University of Pretoria. 


\section{FOUNDATION}

To a certain extent, the Department of Dogmatics could be regarded as the oldest of all the departments in the Dutch Reformed section of the Faculty of Theology. This is the case because George Murray Pellissier, who in 1938 became the founder both of the Department mentioned and the Faculty of which it was part, already started his career as university professor in Pretoria on 1 January 1935. At that stage he started lecturing on behalf of the Dutch Reformed Church in the as yet intact Faculty of Theology that had already been in existence at the University of Pretoria since 1917. The reason why the Dutch Reformed Church joined the Faculty only 20 years after its initial commencement in 1917 will be discussed elsewhere in this volume, relieving the present author of the duty of having to deal with the matter extensively in the current article. What does, however, need to be mentioned is the fact that Pellissier's willingness to accept such a position in extremely uncertain conditions, and against the wishes of the other members of the Faculty staff, broke the impasse which was caused by the uncertainty that prevailed at that stage in Dutch Reformed circles regarding the desirability and feasibility of the Church's involvement in the work of the Pretoria Faculty. Pellissier's acceptance of the position stimulated a movement, which, in due course, led to the establishment of the Dutch Reformed section of the Faculty in 1938 (Pelzer 1978:29). Pellissier not only contributed substantially to the establishment of the academic and administrative foundations of the Faculty, but, through the adoption of an irenic attitude, based on wisdom and unwavering integrity, also succeeded in countering the suspicion with which he was initially regarded. In this way, he also succeeded in winning the confidence of the University authorities concerned (Botha 1946:18).

George Murray Pellissier was born on 7 March 1881 in Bethulie in the Orange Free State, in which province his grandfather, Jean Pierre Pellissier, had already in 1833 established a mission station in the midst of the Barolong people (Van Wyk 1958:1). George Pellissier was, therefore, a descendant of that remarkable group of people, consisting of the children of missionaries who, through the years, contributed greatly to the development of South Africa. The spirit of diligence, dedication and perseverance that characterised such people was, likewise, also inherited by George Pellissier (Keet 1958:20).

In 1898 he matriculated from Grey College in Bloemfontein. Despite initially intending to become a land surveyor, he subsequently felt called to become a minister of religion. With this ideal in mind, he enrolled at the University of Stellenbosch, where he obtained a BA degree at the end of 1902. Pellissier found his student years to be extremely demanding, as he was totally cut off from his parental home, due to the waging of the Anglo-Boer War at the time. In spite of his relative isolation, he progressed well, completing his theological studies by the end of 1906. In the meantime, he simultaneously also, by means of correspondence, started working on a BD course, which was offered by the University of London. Before entering the ministry, he, therefore, went to London for a year, where he obtained the said degree by the end of 1907. While in London, he received a call to minister to the Voortrekker congregation of the Dutch Reformed Church in Pietermaritzburg, which he assumed on his return to South Africa. He continued as pastor to that congregation until 1918, when he moved to that in Dundee. Thereafter, he served the Carolina congregation in the Transvaal from 1924 to 1934 (Van Wyk 1958:4).

As time passed, it became clear that Pellissier was not only a competent and spiritually mature pastor, but also a wise and sympathetic individual. He was able to assist many of his congregants and others to cope with the disastrous effects both of the Anglo-Boer War during the first two decades of the 20th century, as well as the ravaging effects of the Great Depression during the third decade (Van der Merwe 1988:233).
Pellissier's competence and contributions soon found recognition in his denomination, resulting in his appointment to various positions of responsibility. In 1932 he was elected to serve as actuary of the Transvaal synod, as well as chairman of the doctrine committee, which was required to deal with a number of doctrinally sensitive issues. The issues followed on from the so-called Du Plessis controversy, which caused widespread unrest in the Dutch Reformed Church of the late 1920s and early 1930s. Some of the issues to which the Committee had to attend were those pertaining to the authority of Scripture, the divinity of Christ and biological evolution. Appreciation for Pellissier's competence in dealing with these matters found further expression in the fact that, when the Dutch Reformed Church was requested to nominate a person to the position of professor for the Faculty of Theology, his name was put forward.

Publications on the earliest phase of the Dutch Reformed section of the Faculty of Theology usually refer to the fact that Prof. Pellissier was initially made responsible for teaching the dogmatological disciplines (Snyman 1978:38). Though such was generally the truth, the exact state of affairs seems to have been slightly more complicated, and requires a more circumspect description. During the three years from 1935 to 1937, during which Pellissier worked in the as yet undivided Faculty, he mainly taught courses in religious studies and philosophy of religion (Van der Merwe 1988:245). The reason for this was that the Faculty, at that stage, largely operated according to policies which had originally been developed for use by the State Universities in the Netherlands. According to such a duplex ordo system approach, subjects which were based on the presuppositions of religious faith could not be regarded as bona fide university disciplines, but were accommodated in a second category as so-called church subjects (Molendijk 2001). The implication was that, at the Pretoria Faculty, dogmatics was not accepted as a university discipline, but had to be taught on behalf of the church outside the ambit of the formal curriculum. With the establishment of Section B, which was the Dutch Reformed section of the Faculty, the situation changed. The reason, in the case in question, was that the theologians of the church who, mainly, had previously studied in the Netherlands had done so at the Free University in Amsterdam. The Free University had, from its inception, rejected the division of subjects, preferring to operate according to a simplex ordo. During the negotiations that preceded the formation of the Dutch Reformed section of the Faculty, the influential Reverend P. Viljoen understandably argued with conviction in favour of dogmatics being included as a compulsory subject in the BD curriculum (Van der Merwe 1988:266). The result was that when Prof. Pellissier took up his position as first professor of the newly formed Dutch Reformed section of the Faculty, the department in which he was accommodated had been renamed the 'Department of Dogmatics and Science of Religion'. The name was accepted by both sections of the Faculty, as an indication of their common intention that the duplex ordo system, which had been in operation since the inception of the Faculty in 1917, should gradually be phased out.

A study that is currently being undertaken into the initial phase of the Dutch Reformed section of the Faculty fortunately has access to the copious well-preserved notes taken during all the lectures that were presented during the first four years of its existence. Such notes were recorded by L.L.J. Visser, who was one of the first group of six students who enrolled with the Faculty at its inception in 1938. The notes confirm that Prof. Pellissier initially taught Dogmatics and Apologetics, but that Christian Ethics was taught by the New Testament scholar, Prof. E.P. Groenewald, with the discipline Encyclopedia of Theology being taught by the Old Testament scholar, Prof. J.H. Kritzinger. In an attempt to attain greater uniformity in terms of the procedures followed at the Theological Seminary at Stellenbosch, the Encyclopedia of Theology was transferred to the Department of Dogmatics and Science of Religion in 1943, where the discipline was also taught by Prof. Pellissier (Van der Merwe 1988:278). 
A close scrutiny of the initial lecture programme in the Faculty, furthermore, reveals that, during the first four years, Prof. Pellissier taught four consecutive modules of Dogmatics, which covered most of the discipline. During the same period of time, he also taught 14 modules in Science of Religion, in an attempt to maintain as much continuity with the previous programmes of the Department as possible.

In order to form a clear picture of how extensive Pellissier's workload was, one should keep in mind that, during the same period of time, he simultaneously also taught three modules of Apologetics, as well as all four modules in Practical Theology.

For the sake of obtaining a balanced and full assessment of the situation, one should also take note that the courses in Apologetics and Practical Theology did not form part of the official BD programme, but were taught on behalf of the Church. Such was also the case with the three modules in Christian Ethics, which were presented by Prof. Groenewald. It is clear, therefore, that, while a start was made to phase out the duplex ordo system by introducing Dogmatics as a bona fide university discipline, full implementation of a simplex ordo system took some time.

Prof. Pellissier's involvement in the numerous activities pertaining to the establishment of the Faculty meant that he was unable to publish much at the time. Nevertheless, he made a lasting impression on his students, due both to his personal influence, as well as the assistance that he gave them with developing a reliable theological intuition (Van Wyk 1958:5). The theology reflected in the lecture notes of L.L.J. Visser was grounded in the older Reformed tradition, as shown by the many and regular references to the work of such authors as Calvin, Kuyper, Bavinck and Hodge. Pellissier's theology, rather than being an uncritical repetition of this tradition, was an independent interpretation and appropriation of such tradition in the light of contemporary issues and questions. Visser's lecture notes further confirm that Pellissier remained well informed about contemporary developments in the fields of Systematic Theology, accounting for the regular referencing of such authors as Barth, Brunner, Althaus and Berkouwer.

The order in which Pellissier dealt with doctrinal issues in his lectures was derived from that employed in the Belgic Confession (Van der Merwe 1988:303). Thus, he already, during the 1930s and 1940s, informally did what one of his successors, Prof. J.A. Heyns, 50 years later would do in a more formal and methodologically consistent manner, when, in 1992, the latter published an Introduction to Dogmatics, for which he used the Belgic Confession as guideline.

A striking feature of the way in which Pellissier appropriated the Reformed tradition is that he did not succumb to that weakness which so often characterises the tradition, namely that of overintellectualising the Christian faith. He, on the contrary, stressed the interrelatedness of piety and learning. His pursuance of the study of the writings of Pascal played a significant role in this regard (Smuts 1986:218). The Reformed type of piety that he emphasised and illustrated throughout his life was characterised by an overwhelming awareness of the presence of the living Christ. Such a reality determined every aspect of his thought and work, and was the prime criterion in terms of which he evaluated all intellectual and social theories and views, as can be seen in the notes to his lectures and his published sermons (Fensham 1958:37-111). By performing his duties in an exemplary fashion, Pellissier was responsible for founding the Department in a sense more than just being its first lecturer.

The extraordinary workload for which Prof. Pellissier was responsible eventually took its toll in prompting his decision to retire at the end of 1945 . He reacted positively, however, to the request of the Church to continue with training students in the practical subjects. He did so until the end of 1952, when he finally had to relinquish his post due to ill health. He died on 5 March 1954 (Van der Merwe 1988:366-375).

\section{CONSOLIDATION}

On Prof. Pellissier's retirement from the Department of Dogmatics and Science of Religion, he was succeeded by Dr A.B. du Preez at the beginning of 1946.

Andries Bernardus du Preez was born on 28 September 1905 in Senekal in the Orange Free State. After matriculating in 1923, he enrolled at the University of Stellenbosch, from which he obtained a BA in 1926, an MA in Social Sciences in 1928, and a BD in 1929.

In 1930 he enrolled for Systematic Theology studies at the Amsterdam Free University. On 30 June 1933, he was awarded a doctorate in Theology based on a thesis entitled 'Die dualistiese inspirasieleer: 'n Dogmahistoriese ondersoek' (The dualistic theory of Biblical inspiration: A study in doctrinal history), under the guidance of his promoter, Prof. V. Hepp.

According to the dualistic theory of biblical inspiration, some parts of Scripture can be regarded as being infallible, due to their divine inspiration. Other parts, however, are exclusively of human origin and cannot claim such infallibility. Du Preez regarded the dualistic theory, which constituted one of the keenly debated issues during the Du Plessis controversy, as deficient. In his thesis, he argued in favour of what he termed a predestinational organic theory of Biblical inspiration. According to the theory, the human contribution to the origin of Scripture, though valid, is transformed by being taken up into, and guided by, divine intervention.

While he was writing his thesis, Du Preez spent six weeks in Bonn in order to be exposed firsthand to the theology of Karl Barth. His experience was of such a life-changing nature that he developed a lifelong sympathy for Barth's theology.

On his return to South Africa, Du Preez spent 1934 working as a secretary for the Afrikaans section of the Students' Christian Association. During an official visit to the University of Pretoria in April 1934 he encountered S.J. Henrico, who was one of a group of students busy preparing themselves to join the prospective new Dutch Reformed section of the theological faculty. Learning of their need for an organisational structure, in terms of which they might arrange their extracurricular activities, he instigated the official launch of such a student's organisation at a meeting held in the Sonop student's residence on 15 March 1935. Du Preez suggested that the organisation be called 'Deo Gloria'. Throughout his career, Du Preez remained committed to the furtherance of this organisation (Swart 1978:22).

In September 1935, Du Preez entered the parish ministry as the associate minister of the Heidelberg congregation in the Transvaal, becoming its co-pastor a year later. From 1942 to 1945 he served the Waterval congregation in Newlands, a suburb to the west of Johannesburg. During both the pastorates, he dedicated much time and energy to improving the social conditions of his congregants. This aspect of his ministry subsequently impacted on his academic career, as he developed a keen interest in political and social ethics (Swart 1978:69-79). Even his inaugural lecture, which he delivered directly after having been inducted into the professorship of Dogmatics and Science of Religion, reflected such an interest. The title of his lecture was 'The role of the minister of the Gospel in present-day social conditions' (Swart 1978:49).

Prof. Du Preez, rather than being a typical ivory-tower academic, was practically minded and sometimes even combative. His attitudes and actions largely reflected the absolutist and antithetical mentality and ethos of the Reformed community with which he had come into contact in the Netherlands prior to the onset of the Second World War. In terms of such thinking, absolute certainty about Reformed convictions was imperative, with any doubt about such spiritual convictions being equated 
with weakness. Not only was Du Preez's promoter, Prof. V. Hepp regarded, at the time, as a classic example of such an attitude, but so was the early Karl Barth (Aalders 2005:166), who had exerted such a strong influence over the formation of Du Preez's own thinking. Du Preez's students, therefore, knew him as a person who lived according to the motto 'I may be wrong but I am never in doubt!' (Swart 1978:80). Such absolutism is always complemented by the holding of an antithetical attitude. In terms of such an attitude, points of view have to be formulated in polemical terms, and should preferably be aimed at either a real or a fictitious adversary. Fortunately with Du Preez, such absolutism and antithesis were tempered by a unique sense of humour and a pervading charm (Jonker 1973:233).

Du Preez's practical nature even resulted in his involvement in a wide variety of ecclesiastical, cultural and social committees and their activities. Especially noticeable was the role that he played as a member and, subsequently, as the chairperson of the Synodical Committee for Current Affairs and Ethical Issues for his denomination.

The stress that this article has, so far, lain on Du Preez's involvement in practical church and cultural matters does not imply that he neglected the academic domain. Despite not developing a comprehensive and coherent own system of thought, the contribution that he made was rather that of an educator and facilitator of a South African context, which was conducive to original and solid theological work. Although the basic orientation with which he infused his students consisted of the traditional Reformed theology of Calvin, Kuyper, Bavinck and Hepp, he also exposed them to contemporary developments, as represented by the thinking of Barth, Brunner and Berkouwer. He continued to be fascinated by the writings of Barth, while being critical of certain aspects of his theology. Throughout his career, he implemented Barth's well-known custom of offene Abenden, which consisted of him extending a monthly invitation to his students to join him at his home in the discussion of theological questions (Swart 1978:83). Though his students wondered about his blending of his loyalty to the scholastic theology of his mentor Hepp with his enthusiasm for the dialectical theology of Barth, they clearly saw that his work was characterised by an all-pervasive respect for the authority of Scripture. Such respect provided a basic framework that allowed for the accommodation of a variety of oft conflicting theological positions in a broadly orthodox way (Jonker 1973:234).

Du Preez's contribution to the theological scene in South Africa was not restricted to his work as an educator, as he also undertook research, even prior to his professorship. In December 1934, together with other Afrikaans-speaking theologians, he became involved in establishing a theological society called the SuidAfrikaanse Teologiese Studiekring (the South African theological study circle). The aim of the organisation was to assist with the development and articulation of theories and emphases characteristic of Afrikaans contributions to theology. Du Preez also helped to publish a journal called Woord en Waarheid (Word and Truth), in which the writings of members of the Studiekring were published.

Du Preez boosted the research effort of his department by supervising the completion of the dissertations of its first four doctoral candidates, namely G.J. Swart, F.P. Möller, W.J. Murray Janson and A. König (Swart 1978:54).

Du Preez will be remembered for two specific views of his that had a noticeable impact on the work not only of his department, but on that of the Faculty as a whole. The first relates to the question of in which part of the curriculum the discipline dealing with church polity should be taught, and the second to the question as to whether the work of theological doctors should be regarded as ecclesiastical or as purely educational.

As far as the first question is concerned, Du Preez argued that Church Polity should be taught as part of the doctrinal, rather than as part of the historical, subjects. The reason that he gave for his adoption of such an approach was that Church Polity does not primarily focus on the history of legal arrangements and procedures regarding the organisation of church life, but rather on the truth of Biblical principles in this regard (Du Preez 1967:10). A failure to teach the subject as part of Dogmatics, according to his way of thinking, is based on an unbiblical notion of the church, in which the church is seen as an exclusively human organisation, rather than as one instituted by Christ. As a result of this outlook, Du Preez taught Church Polity as part of Dogmatics during his professorship (Swart 1978:63). An extensive unpublished manuscript which he wrote for the course is still available. After Du Preez's retirement, Church Polity, for practical reasons, reverted to the Department of Church History.

Du Preez's views on the role of theological doctors had relevance both for his own department, and for the Faculty as a whole. He argued that the work of those who have the responsibility of training candidates for the ministry is primarily of an ecclesiastical, rather than of an exclusively educational, character. The holding of such a view, according to his way of thinking, inevitably led to the conclusion that theology, even when it is taught in the context of a state university, is of an ecclesiastical, rather than of a purely academic, nature (Du Preez 1962:43). He held that such a state of affairs had two implications. The first was that the church should not surrender control over the theological training of its candidates. The second was that those lecturers who teach theology should remain actively involved in church life, so as not to become alienated from the ethos of the institution for which they are providing training.

Taking into account everything that has been said about the life and work of Prof. A.B. du Preez, the conclusion would not be inappropriate that, while George Pellissier can be regarded as the founder of the Department, Du Preez can be seen as its consolidator. He was a colourful character with a strong and often idiosyncratic way of thinking, which sometimes led to disagreements with colleagues (Du Preez 1955,1959). He did, however, contribute substantially to the consolidation of structures within whose walls the development of Systematic Theology in South Africa could be strongly stimulated (Jonker 1973:234)

During his professorship, the name of the Department was, in 1952, changed from that of Dogmatics and Science of Religion to Dogmatics and Christian Ethics. The available historical documents do not clearly indicate what role Du Preez played in the change of name. In terms of his views on the nature of theology as an academic discipline, it is, however, clear that he would actively have promoted such a change in name. Another reason might have been that the new name reflected the state of affairs that existed at the time in the Stellenbosch faculty, as well as that which prevailed at the Free University in Amsterdam. The Dutch Reformed members of the Faculty in Pretoria had, after all, maintained close and constant contact with both institutions.

Having reached the mandatory retirement age, Du Preez left the employ of the University before the end of 1970. Three years later, on 9 February 1973, he unexpectedly died of a heart attack.

\section{INNOVATION}

A.B. du Preez was in 1971 succeeded in his role as professor in the Department by J.A. Heyns. Johan Adam Heyns was born in Tweeling, a town in the Orange Free State, on 27 May 1928. Having matriculated in 1945 from the Gimnasium High School in Potchefstroom, Heyns studied for three years at the Potchefstroom University for Christian Higher Education. The first phase of his university studies proved to be of decisive significance for his subsequent academic career, as it was during this time that he came into contact with, and internalised, 
the Calvinistic lifestyle and world view which prevailed in the institution. Through the influence of the well-known philosopher, H.G. Stoker, who became his lifelong mentor and friend, he became an ardent promoter of the ideals of a Christian philosophy and science.

Heyns' ideals brought him into conflict with his Dogmatics Professor, A.B. du Preez, when in 1949 he came to the University of Pretoria to study for his BD degree. Du Preez was opposed to the idea of a Christian science for two reasons. Firstly, he shared the idea of his promoter Hepp that philosophers were not necessarily competent theologians, and that their attempt to involve themselves in it could only lead to 'amateurish tinkering' (Van Deursen 2005:175). Secondly, Du Preez agreed with Karl Barth's fear that the idea of a Christian science presupposes the existence of some kind of natural theology, as is the case with the Roman Catholic analogia entis doctrine. Barth, at one stage, even called the analogia entis doctrine a discovery of the Antichrist, which, according to Meiring (1994:178), occasioned Du Preez, one day in class, to say to his new student: 'Mr Heyns, I tell you, Christian science is evil.' On encountering such opposition, Heyns considered the possibility of discontinuing his studies in Pretoria, but then determined to persevere in order 'to change the situation from the inside'

Although such an incident did not amount to an all-out conflict, it serves well as an illustration of two elements which, later, would come to characterise Heyns' modus operandi. As Du Preez had done before him, Heyns often used seemingly controversial and even shocking statements as a didactical and rhetorical mechanism to draw out and retain the attention of his students, and to elicit reaction from them (Williams 2006:19). The second noteworthy element is that of Heyns' propensity for loyalty, perseverance and tenacity when he was convinced of the validity of a particular view or position. In the often complex and ambivalent situations in which the Dutch Reformed Church, the Afrikaans community and Reformed theology found itself in South Africa, Heyns' solidarity, albeit critical at times, with his fellow believers could not be doubted (Willims 2006:34).

The academic background to Heyns' professional career requires further elucidation. After completing his BD and MA (Philosophy) degrees at the University of Pretoria, Heyns, at the end of 1951, chose to study Systematic Theology under Prof. G.C. Berkouwer, whom he had already met during the latter's visit to Pretoria in 1950, in Amsterdam (Williams 2006:23).

He completed his doctorate in 1953, with the successful submission of a thesis on 'The basic structure of the modalistic doctrine of the Trinity'. During his two years in Europe, he came into personal contact with Prof. D.H. Th. Vollenhoven, one of the original Dutch proponents of the idea of a Christian philosophy, as well as with the influential Swiss theologians Karl Barth and Emil Brunner (Williams 2006:23).

On his return to South Africa, Heyns entered the ministry, serving the Ysterplaat congregation from 1954 to 1960, and, from 1961 to 1965, the Dutch Reformed congregation in Rondebosch, Cape Town. In 1966 he was appointed senior lecturer in Systematic Theology at Stellenbosch University, becoming professor in, and head of, the Department of Dogmatics and Christian Ethics at the University of Pretoria in 1971, from which position he retired in January 1992. For two years after his retirement, he continued to lecture in the Department in a temporary capacity.

Since the inception of the Department in 1938, the idea of a theology formulated in an own Afrikaans idiom was nurtured. Both Pellissier (Visser 1958:27; Williams 2006:19) and Du Preez (Swart 1978:23) repeatedly expressed their belief in such an ideal. Their belief was articulated in even stronger terms by Prof. Heyns in his inaugural lecture in 1971, in which he reflected upon contemporary developments in Systematic Theology. He had encountered those developments during a sabbatical, which he had spent in Western Europe during the first semester of 1970. As many such developments deviated from what he regarded to be the traditional Reformed position, a uniquely Afrikaans response was necessary. Heyns was not satisfied with merely expressing his wish to uphold such an ideal. His construction of his own system of thought as a fitting response was facilitated by him having, early on in his career, in conjunction with the ideas of Stoker, developed a basic theological framework. In terms of the framework, all the aspects of the various Systematic Theological disciplines, such as Dogmatics, Apologetics and Christian Ethics, could be dealt with in an original way (Strauss 1994:95). Such a development resulted in the production of an impressive body of work, comprising 40 books, as well as a large number of both academic and popular articles. This extensive auvre, which includes both a comprehensive textbook on Dogmatics, as well as a three-volume work on Theological Ethics, is probably unparalleled in the Afrikaans context.

The basic category which lends coherence to Heyns' system of thought is that of the Kingdom of God. According to him, the Kingdom of God will come about when God's reign elicits an obedient response from the whole of creation. Within such a context, Heyns refers to human obedience as the immanent subjective correlate of the Kingdom of God (Heyns 1972:49). The influence of his mentors on his work is apparent. The notion of the kingdom of God as an ontological category, in all probability, has its origin in Stoker's philosophy regarding creation, while the acknowledgment of the correlative relationship between the kingdom of God and human obedience clearly derives from the correlation motif which characterises Berkouwer's theology (Jonker 1994:15). Rather than showing that Heyns' work is a mere repetition of that of his teachers, the above findings recognise that his work serves as an independent appropriation of such influences and as an original rendering of an all-encompassing vision of the kingdom of God, which results from obedience. In this sense, his theology can be described as a theology of obedience. Irrespective of whatever influences can be detected, Heyns himself was convinced that his views, in the last resort, were an attempt to describe the basic pattern of God's intentions for the world, as described in the Bible (Heyns 1994:164). His strong rejection, at the end of his career, of the idea that philosophical influences on his work led to a natural theology, as could be seen in his response to Du Preez 40 years earlier, is therefore understandable (Heyns 1994:166).

Shortly before his final retirement in 1993, Heyns participated in a symposium on his theology, which was held at the University of Pretoria. The enthusiastic and dynamic way in which he entered into the debate was characteristic of his style of lecturing. He often described the relationship between lecturer and students as resembling that of a senior and junior partner involved in a joint venture (Wethmar 1993:10). He was convinced that the only appropriate way in which students might adequately repay a teacher was to gain independence themselves (Wethmar 1994:65). He, therefore, never required a student to echo his views, but rather that they develop and articulate their own points of view (Lategan 1995:5).

Closely related to such an approach is the conviction, which continued to be propagated by his successors, that Heyns asserted from the mid-1980s onwards that a vital part of the responsibility that a university should assume for its students is that of sensitising them to the moral dimensions of all academic and scientific work. The task of a university, he said, entails much more than merely supplying the economy with highly skilled human resources. A university should also function as the academic conscience of society (Heyns 1986:301).

Heyns was an excellent communicator, who was always willing to speak his own mind, both in the classroom and in the public sphere. His outspokenness made him a popular lecturer, who was often approached to act as the supervisor of the writing of theses. During his term of office, Prof. Heyns supervised the completion of 20 doctoral theses. 
Heyns' achievements in the academic sphere are all the more impressive if one takes into account that such work was undertaken while he, simultaneously, occupied a variety of leadership positions in church, university and civil society. A few examples in this regard will suffice. He was the moderator of the important 1986 general synod of the Dutch Reformed Church as well as the chairperson of the doctrine committee from 1982 to 1994 . From 1981 to 1984 he was dean of the faculty in which he worked, and, for a number of years, he was also a member of the University Council. He also served one term as chairperson of the Suid-Afrikaanse Akademie vir Wetenskap en Kuns (the South African Academy for Science and the Arts). Heyns' work was rewarded with a number of prestigious prizes and awards.

The impressive career of Prof. Heyns was ended with unforeseen brutality by his assassination in his home on 5 November 1994. Neither the identity of the killer, nor the motive for such a senseless murder, has, as yet, become known. Measures were immediately taken for an appropriate commemoration of the significant contribution that he made to both the University and the Church. He was therefore, in 1995, posthumously awarded an honorary doctorate in divinity. An annual Johan Heyns memorial lecture was instituted in 2005 by both the Department of Dogmatics and the ministry committee of the Dutch Reformed Church.

Since the mid-1970s, the number of theological students at the Faculty of Theology has increased significantly. The development was largely due to the institution of an evangelical programme which was aimed at young people, the so-called jeug-tot-jeugaksie, which was conducted in the Dutch Reformed Church in 1974 (Smuts 2002:207). To cope with the increased number of students, an additional lecturer was appointed to each of the departments, with Prof. D.A. du Toit joining the Department of Dogmatics and Christian Ethics in 1976. On his leaving to take up a position at Stellenbosch University at the end of 1977, he was succeeded by Prof. P.C. Potgieter in 1978. Potgieter worked in the Department until the end of 1980, when he left to help develop a new theological faculty in Bloemfontein. During their respective terms of office in Pretoria, both Du Toit and Potgieter mainly worked in the field of Christian Ethics. In their subsequent careers, both have made important contributions to the development of theology and the Church in South Africa.

\section{CONTINUATION}

The second post in the Department was occupied on a more permanent basis when Potgieter, in January 1981, was succeeded by Conrad Wethmar. During 1981 and 1982, Wethmar taught Christian Ethics. From 1983 onwards, however, hewas responsible for dogmatics, doctrinal hermeneutics and the Encyclopaedia of Theology. When Johan Heyns retired in January 1992, Wethmar succeeded him as head of the Department.

Conrad Johannes Wethmar was born on 25 May 1943 in Johannesburg. He grew up in Florida, a town to the west of Johannesburg, where he matriculated in 1961. In the following year he enrolled at the University of Stellenbosch for studies which served as the entrance requirement for further studies in Theology. At that stage, he developed a special interest in classics and philosophy. The result was that, after completion of a BA degree with Greek, Hebrew and Philosophy as majors, he also obtained honours degrees in Greek (1966) and Philosophy (1968), as well as a Master's degree in Greek (1969). From 1966 to 1969 he, simultaneously, also studied at the Faculty of Theology, completing a BTh degree in 1968 and a Licentiate in Theology in 1969.

During his theological studies, Dogmatics attracted his attention, due to the similarities between that discipline and the disciplines of classics and philosophy. Dogmatics requires the ability to interpret historical texts accurately, as well as competence in the systematic and coherent determination of the relevance of such texts for a present-day life of faith. Feeling the need to deepen his insight in the subject, Wethmar studied further under Prof. G.C. Berkouwer in Amsterdam from the start of 1970. His obtaining of his doctorate in May 1977 by means of the successful submission of a thesis on doctrinal hermeneutics, already indicated his preference of a hermeneutical approach towards questions of a doctrinal nature. His adoption of such an approach would lead to his later assumption of a position marked by dialogical orthodoxy. Research into the complex nature, function and relevance of theological creeds became a long-lasting concern of his.

From 1977 to 1980 Wethmar taught Systematic Theology at the University of Durban-Westville, where he trained ministers of the Reformed Church in Africa. As already mentioned, he joined the University of Pretoria in 1981, from which he retired on 1 July 2008.

Throughout his career, he represented an ecumenical Reformed Dogmatics, applying the Reformed tradition to solving presentday issues and questions. He consistently taught that the basic contribution that the Reformed tradition makes to the ecumenical church is that of combining in an authentic biblical manner, the faith-related dimensions of knowledge, spirituality and morality. He emphasised the importance and relevance of orthodoxy for the life of the church, on the condition that such orthodoxy functions in a dialogical and doxological way (Wethmar 2003b:648).

From January 1997 to December 1999, while Wethmar was Dean of the Dutch Reformed section of the Faculty, the amalgamation of the previously separated church sections of the Faculty took place. An approach that was characterised by dialogical orthodoxy proved helpful in the development of the theological basis and institutional structures required for the establishment of an ecumenical faculty (Wethmar 1998, 2003b). Wethmar indicated that confessionality, on the one hand, and historicity and ecumenicity, on the other, did not have to be mutually exclusive (Smit 2008:467; Wethmar 1998:8).

Wethmar also continuously argued that academic theology plays a vital role in the life of a church which deliberately espouses the Reformed tradition of being a church of the Word. In this regard, he often referred to Gerhard Ebeling's saying that the task of theology entails making preaching in the church as difficult as necessary (Ebeling 1967:447). In terms of such thinking, a fundamental concern of theology should be to live with the Word of God in such a way that the Word remains recognisable as the Word of God.

The increase in postgraduate student numbers that started in the mid-1970s continued for the next three decades, resulting in Wethmar's supervision of 25 doctoral theses to completion. A noticeable new development was also that increasingly more students from other African and Asian countries, as well as from other South African denominations, undertook studies in the Department.

As was the case with his predecessors, Wethmar was also active in various Church circles. From 1981 to 2004 he was a member of the doctrine committee of the general synod of the Dutch Reformed Church, with him being the chairperson of the committee from 1998 to 2004. In 1984 and 1988 he was also one of the representatives of the Dutch Reformed Church at meetings of the Reformed Ecumenical Council. From 1995 onwards, he was involved with affiliating the Dutch Reformed Church with the South African Council for Theological Education, as well as with the establishment of a Forum for University Theological Education.

When Prof. Johan Heyns, by the end of 1993, left the employ of the University, he was succeeded by Prof. D.E. de Villiers. Prof. Heyns, in 1978, already indicated that Ethics as a discipline had become so important that it would be desirable to have a 
full-time member of staff dedicated to the discipline (Snyman 1978:37). When Prof. De Villiers joined the Department, such an ideal was realised by his assumption of responsibility for all Ethics courses.

Dawid Etienne de Villiers was born as a pastor's son in Wellington in the Western Cape on 7 October 1945. On matriculating, he obtained both an MA degree in philosophy, as well as a BTh degree from Stellenbosch University. While a student, he edited the students' weekly paper Die Matie, as well as serving as the chairperson of the Students' Representative Council. The exposure which such appointments afforded him in campus politics, at a time of great upheaval in South African society, exposed him to the asking of incisive questions, which played a meaningful role in his subsequent academic career.

As was the case with most of his predecessors in the Department, he also attended the Free University in Amsterdam for his further studies in Systematic Theology. Though his initial plan was to study dogmatics under Prof. G.C. Berkouwer, h e later decided to pursue studies in theological ethics under Prof. H.M. Kuitert, obtaining his doctorate in 1978 with his successful submission of a thesis on 'Die eiesoortigheid van die Christelike moraal' (The distinctive nature of Christian morality). Such a change in direction resulted from his growing awareness that his primary interest lay not in exclusively ecclesiastical issues, but rather in seeking answers to questions pertaining to the social, economic and political relevance of Christian convictions (Bezuidenhout 2007:171).

On De Villiers' return to South Africa in 1978, he started teaching Christian Ethics and Youth Work at the Huguenot College in Wellington and, as already mentioned, in January 1994 he moved to the University of Pretoria. Here, in a number of ways, be succeeded in realising the ideals that had already existed in the Department of Dogmatics and Christian Ethics. He, for example, initiated a Centre for Professional Ethics, which was subsequently moved to the Department of Philosophy, but in which he is still involved, especially in terms of his development and presentation of a course in engineering ethics.

In 2007, Prof. De Villiers, in addition to his normal activities, was also appointed Director of the Faculty's Centre for Public Theology. Being a Von Humboldt stipendiary and a member of the Princeton-based Centre for Theological Inquiry, he was able to develop an extensive international network, which benefits the development and work of the Centre.

For most of his career, De Villiers was an avid supporter of the work of the Theological Society of Southern Africa, as well as serving as its chairperson for a number of years.

Over the years, the work of Prof. de Villiers developed a characteristic own profile (Bezuidenhout 2007:164-245). Coming from a fairly evangelical, and even pietistic, background, the first phase of his career was characterised by an attempt to adapt to the process of modernisation, which he encountered in Stellenbosch and Amsterdam. The result of this attempt can be seen in De Villiers' doctoral thesis, in which he contradicts his promoter's claim that ethical statements are, in the last resort, based on a natural self-establishing plausibility. De Villiers argued that Christian morality has a specific content of a more than human origin and authority.

The second phase in the development of De Villiers' academic career coincided with the work that he undertook in Wellington between 1978 and 1993. Exposure to the traumatic political situation that prevailed in those years led him to focus especially on those social ethical issues related to justice and peace. As well as his many contributions to publications critical of the policy of apartheid, his defence in different forums of the idea that Christians are called to conquer enmity as such, and not a particular enemy, was especially noteworthy.
The third phase of De Villiers' theological development occurred during his work in Pretoria, which started at the same time as a new political dispensation was brought about in the country. At that stage, his attention was mainly focused on the question of what the task of the church and Christian ethics is in the public sphere of a liberal democracy.

Although it proved possible to distinguish between three different phases in De Villiers' career, close scrutiny reveals that all three phases, in fact, represent different manifestations of the one basic question, relating to the distinctive identity of Christian morality, in response to which the answer assumed different forms. The answer in the first phase was grounded in ethical consciousness, as the motivation for performing, as well as the contents of, the relevant duty. Gradually, however, De Villiers became convinced, together with Hauerwas, that the distinctive identity of Christian morality could better be located in the virtues and attitudes of believers, in which the Biblical narratives regarding God and Christ play an indispensable formative role.

In the third phase of his career, De Villiers developed the conviction that, while distinctive virtues and attitudes are necessary motivations for Christian behaviour, they are not the only elements involved. Christian values interact with functional values that are specifically related to a particular situation and action. Whether the interaction occurs in such a manner that justice is done to both kinds of values is a vital consideration in terms of Christian ethics. According to De Villiers, an adequate answer to the question can be found if Christian ethics operate in terms of an ethics of responsibility.

Taking into account the independent and consistent manner in which De Villiers, for a period of more than three decades, developed the notion of a Christian ethic, it becomes clear that he realised one of the basic ideals that has consistently characterised the work of the Department, namely that of developing its own particular theological position.

To all intents and purposes, such a realisation of the aforementioned ideal can also be expected from the most recent appointee to the Department. When Prof. Wethmar retired, he was succeeded by Prof. D.P. Veldsman. Daniël Petrus Veldsman was born in Grahamstown in 1959. Having obtained a BA degree at the University of Port Elizabeth in 1981, he continued with his studies at the University of Pretoria, being awarded a BA (Honours) degree in Greek in 1983, and a BD in 1984. Part of his doctoral studies entailed the studies that he conducted at the Kirchliche Hochschule in West Berlin, under the supervision of Prof. Walter Schmithals. In 1989 he completed his doctorate under the guidance of Prof. Conrad Wethmar as his promoter. The title of his thesis was Etisering- personalisering eksistensialisering van die geloofsbegrip (An ethical, personalist and existentialist approach to faith).

From 1989 to 1996 he worked as a research specialist at the library of Pretoria University, and from 1997 to 1999 as full-time minister of a Dutch Reformed congregation in Pretoria. From 2000 up until his appointment at the University of Pretoria, he taught Systematic Theology at the University of South Africa.

Veldsman's doctoral thesis already indicated an own theological emphasis, which was in the process of development. As his career progressed, such an emphasis became more prominent. His theological outlook, which emphasises the role of experience, allows for consideration of issues that traditionally played an important role in Protestant theology - Luther's statement 'sola experientia facit theologum' comes to mind. However, such an outlook also opens up possibilities for attending to current developments, such as for the exploration of the relationship between theology, on the one hand, and visual arts, film and music, on the other. Such a development complements the already existing perspective of the Department. 


\section{CONCLUSION}

The initial intention of the current article was to assess the work that the Department has undertaken over the 70 years since its inception in 1938, with a due emphasis on the comparison of its achievements with their accompanying expectations, as expressed by the Dutch Reformed Church, the University of Pretoria and civil society. During the 70 years concerned, dramatic changes took place in all three such contexts, with the expectations changing accordingly. To give a simple, straightforward answer to the initial question is impossible, as a range of factors must be taken into account.

Overall, the role played by members of the Department in the development of the Dutch Reformed Church was positive, which is reflected by the performance of important tasks regularly having been entrusted to them. Professors of Dogmatics and Ethics in the Church were often viewed as being the official authority on doctrinal and moral issues in a particular church and society (Berkhof 1985:20). To a certain extent, such might be said to hold true for members of the Department, up until the 1980s. As the role of the church in society decreased, however, the role of official doctrinal and ethical spokespersons also became less prominent.

Both within the broader University context, as well as in the Faculty of Theology, the contribution made by dogmatists and ethicists was generally appreciated. One should, however, be aware of the fact that the ethos and procedures of the university system in South Africa have undergone significant changes during the last two decades especially. Since the 1990s, research-related administrative procedures have increasingly been determined by the manner in which the natural sciences have come to operate in the global context. The redirection of focus has led to a situation in which those disciplines which presuppose a confessional dimension could only with difficulty be accommodated. Such a situation demands urgent attention.

When considering the work of the Department in terms of the broader South African community, the need that the Department consistently saw for articulating the traditional ecumenical Reformed position prevailed. For the first 50 years of the Department's history, such articulation was, generally speaking, appreciated by the community in which it was located. Since the 1980s the cultural context within which the Department has worked has become increasingly characterised by secularisation and pluralism, both of which factors have rendered ever more complex the process of communication. Faced by such an ongoing challenge, preliminary attempts are being undertaken in the field of public theology to manage the situation to the benefit of the greater community.

Describing the history of an institution in which one is personally involved is not easy, as the danger of hagiography is ever present. Cognisance should, therefore, be taken of the fact that, when reference was made to the expectations of the Department, a critical item was omitted. That is the expectation which is harboured by the one about whom, etymologically speaking, theology is called to talk. In the light of such an expectation, all theologians become intensely aware of their own limitations. At the same time, however, one realises that the final judgement of one's life and work is not a human one. Such judgement rests with one whom we confess to be our gracious Father, who endows individuals with gifts, which they can thankfully dedicate to his service. This contribution is, therefore, not only written with the Hippocratic adage ars longa vita brevis in mind, but also with that of the motto which is inscribed on a painting which hangs in the committee room of the Faculty concerned: Deum colere paret veram aequitatem.

\section{REFERENCES}

Aalders, M., 2005, 125 jaar Faculteit der Godgeleerdheid aan de Vrije Universiteit, Meinema, Zoetermeer.
Berkhof, H., 1985, Introduction to the study of dogmatics, Eerdmans, Grand Rapids.

Bezuidenhout, R.M., 2007, 'Re-imagining life: A reflection on 'public theology' in the work of Linell Cady, Denise Ackermann and Etienne de Villiers', PhD thesis, Nelson Mandela Metropolitan University.

Botha, M.C., 1946, "n Woord van waardering', in W. Nicol (red.), Die ontstaan en groei van ons Teologiese Fakulteit en huldebetoon aan die grondlegger Prof G M Pellissier, pp. 18-19, Voortrekkerpers, Pretoria.

DuPreez,A.B.,1933,Diedualistiese inspirasieleer:'n Dogmahistoriese ondersoek, Meinema, Delft.

DuPreez,A.B.,1955,DieSkriftuurlikegrondslagvirrasseverhoudinge, Nasionale Handelsdrukkery, Elsiesrivier.

Du Preez, A.B., 1959, Eiesoortige ontwikkeling tot volksdiens, HAUM, Kaapstad.

Du Preez, A.B., 1962, 'Die kerklike Doktore-amp', Ned Geref Teologiese Tydskrif 4(1), 36-47.

Du Preez, A.B., 1967, 'Die ensiklopediese plek van Kerkreg', Deo Gloria-blad, 9-11.

De Villiers, D.E., 1978, Die eiesoortigheid van die Christelike moraal, Rodopi, Amsterdam.

De Villiers, D.E., 1984, 'Kerklike standpunte sedert die instelling van die wette', in E. de Villiers and J. Kinghorn (eds.), Op die Skaal: Gemengde Huwelike en Ontug, pp. 54-77, Tafelberg, Kaapstad.

De Villiers, D.E., 1986, 'Kritiek uit die ekumene', in J. Kinghorn (ed.), Die NG Kerk en Apartheid, pp. 144-164, Macmillan, Johannesburg.

Ebeling, G., 1967, Wort und Glaube I, Mohr, Tübingen

Fensham, F.C. (ed.), 1958, Professor G M Pellissier, NG Kerk Uitgewers, Kaapstad.

Henrico, S.J., 1929-1940, Ongepubliseerde dagboek.

Heyns, J.A., 1953, Die grondstruktuur van die modalistiese Triniteitsbeskouing, Kok, Kampen.

Heyns, J.A., 1971, Die huidige stand van die Gereformeerde teologie in Nederland en ons verantwoordelikheid, Van Schaik, Pretoria.

Heyns, J.A., 1972, Lewende Christendom: 'n Teologie van gehoorsaamheid, Tafelberg, Kaapstad.

Heyns, J.A., 1978, Dogmatiek, NG Kerkboekhandel, Pretoria.

Heyns, J.A., 1982, Teologiese etiek, Deel 1, NG Kerkboekhandel, Pretoria.

Heyns, J.A., 1986, Teologiese etiek, Deel 2/1, NG Kerkboekhandel, Pretoria.

Heyns, J.A., 1989, Teologiese etiek, Deel 2/2, NG Kerkboekhandel, Pretoria.

Heyns, J.A., 1992, Inleiding tot die dogmatiek aan die hand van die Nederlandse Geloofsbelydenis, NG Kerkboekhandel, Halfway House.

Heyns, J.A., 1994, "n Weerwoord', Skrif en Kerk, 15(1), 156-176.

Jonker, W.D., 1973, 'In memoriam Prof Andries Bernardus du Preez', Ned Geref Teologiese Tydskrif 14(4), 233-234.

Keet, D.J., 1958, 'Professor Pellissier as kollega', in W. Nicol (ed.), Die Ontstaan en Groei van ons Teologiese Fakulteit en Huldebetoon aan die Grondlegger Prof G M Pellissier, pp. 20-22, Voortrekkerpers, Pretoria.

Lategan, L.O.K., 1995, 'Beste professor: 'n Huldeblyk aan J A Heyns', Ned Geref Teologiese Tydskrif 36(1), 4-8.

Meiring, P.G.J., 1994, "n Huldigingsartikel: Johan Heyns - Man van die kerk', Skrif en Kerk 15(1), 177-184.

Molendijk, A.L., 2001, 'De beoefening van de theologie aan openbare instellingen van hoger onderwijs', in H.J. Adriaanse (ed.), Tweestromenland over wijsgerige en belijdende theologie, pp. 31-52, Peeters, Leuven.

Pelzer, A.N., 1978, 'Die verhouding Teologiese Fakulteit (Afdeling B) en Universiteit', Deo Gloria blad, 29-35.

Skinner, T., 1996, 'Die lewe en werk van Johan Adam Heyns: 'n Kerkhistoriese perspektief', BD thesis, University of Pretoria.

Smit, D.J., 2008, 'Confessional and ecumenical? Revisiting Edmund Schlink on the hermeneutics of doctrine', Verbum et Ecclesia 29(2), 446-474. 
Smuts, A.J., 1986, 'G M Pellissier oor die prediking', Skrif en Kerk $7(2), 212-218$.

Smuts, M., 2002, 1974, 'Jeug tot jeug', G. Hofmeyr (ed.), NG Kerk 350: Eenhonderd bakens in die geskiedenis van die Nederduitse Gereformeerde Kerk 1652-2002, pp. 206-207, Lux Verbi, Wellington.

Strauss, S.A., 1994, 'Johan Heyns as apologeet', Skrif en Kerk 15(1), 95-107.

Strauss, S.A., 2002, 'Pieter Potgieter as mens en teoloog: Essensieel en eietyds', in D.F. Tolmie(ed.), Essentialia et Hodierna: Oblata, P.C. Potgieter (Acta Theologica, Supplementum 3), 1-16.

Swart, L.C., 1978, 'Die lewe en werk van Andries Bernardus Du Preez', Postgraduate Diploma thesis, University of Pretoria.

Van der Merwe, P.A., 1988, 'George Murray Pellissier, 18811954: Die lewensbeeld van 'n kerkman', thesis, University of Pretoria.

Van der Watt, P.B., 1987, Die Nederduitse Gereformeerde Kerk, 1905-1975, NG Kerkboekhandel, Pretoria.

Van Deursen, A.Th., 2005, Een hoeksteen in het verzuild bestel: De Vrije Universiteit, 1880-2005, Bakker, Amsterdam.

Van Wyk, J.A., 1958, "n Seder val in Libanon', in F.C. Fensham (ed.), Professor G M Pellissier, pp. 1-9, N G Kerk Uitgewers, Cape Town.

Veldsman, D.P., 1989, Etisering, personalisering, eksistensialisering van die geloofsbegrip, DD thesis, University of Pretoria.
Visser, L.L.J., 1938-1941, Ongepubliseerde Klasaantekeninge, Faculty Theology, University of Pretoria.

Visser, L.L.J., 1958, 'Geliefde Professor', in F.C. Fensham (ed.), Professor G M Pellissier, pp. 19-33, NG Kerk Uitgewers, Cape Town.

Weinrich, M., 1999, Theologie und Biographie: Zum verhältnis von Lehre und Leben, foedus-Verlag, Wuppertal.

Wethmar, C.J., 1977, Dogma en verstaanshorison, Rodopi, Amsterdam.

Wethmar, C.J., 1993, 'Die junior vennoot in die teologiese laboratorium', Deo Gloria-blad, 10-11.

Wethmar, C.J., 1994, 'Wetenskaplikheid en konfessionaliteit van die teologie: Enkele gesigspunte in verband met die teologiebegrip van J A Heyns', Skrif en Kerk 15(1), 65-74.

Wethmar, C.J., 1998, 'Die toekoms van teologiese opleiding in die Nederduitse Gereformeerde Kerk', Ned Geref Teologiese Tydskrif, 39(3), 220-230.

Wethmar, C.J., 2003, 'Theological education in an ecumenical context: Principles and procedures of the Pretoria model', in M.E. Brinkman, N.F.M. Schreurs, H.M. Vroom \& C.J. Wethmar (eds.), Theology between Church, University and Society, pp. 61-74, Van Gorcum, Assen.

Wethmar, C.J., 2003b, 'Teologiekroniek: Die nuwe hervorming en die ortodoksie', Verbum et Ecclesia 24(2), 644-649.

Williams, H.H., 2006, 'J.A. Heyns en die Nederduitse Gereformeerde kerk en apartheid', DTh thesis, University of the Free State. 